\title{
ANALISIS ALUR PELAPORAN PREKURSOR DAN OBAT-OBAT TERTENTU (OOT) DI APOTEK
}

\author{
Peppy Octaviani ${ }^{1 *}$, Retno Agus Setiawan ${ }^{2}$ \\ ${ }^{1}$ ProgramStudi Sarjana Farmasi, Fakultas Ilmu Kesehatan, Universitas Harapan Bangsa \\ ${ }^{2}$ Program Studi Sistem Informasi, Fakultas Ilmu Sosial, Universitas Harapan Bangsa \\ *Email: Octavianipeppy@ gmail.com
}

Received: 02/07/2021, Revised: 03/08/2021, Accepted: 04/08/2021, Published: 18/08/2021

\begin{abstract}
ABSTRAK
Bahan baku prekursor merupakan bahan dasar dalam pembuatan psikotropika dan narkotika. Prekursor dapat disalahgunakan oleh pelaku kejahatan dalam pembuatan psikotropika dan narkotika. Penyalahgunaan prekursor biasanya digunakan sebagai obat penenang. Penyalahgunaan terhadap obat-obat golongan narkotika, psikotropika dan obat lain yang mengandung prekursor menurun seiring bertambah ketatnya pengawasan, namun beberapa tahun terakhir penyalahgunaan terjadi pada beberapa obat lain yang memiliki efek serupa dengan narkotika dan psikotropika, yaitu obat dengan komposisi zat aktif Dekstrometorfan dan Karisoprodol. Setelah Badan POM menindaklanjuti penyalahgunaan dengan penarikan NIE Dekstrometorfan sediaan tunggal dan Karisoprodol, penyalahgunaan beralih kepada Tramadol, Haloperidol, Triheksifenidil, Amytriptilin, Klorpromazin yang selanjutnya disebut sebagai obat-obat tertentu (OOT). Apotek sebagai tempat yang banyak menyalurkan prekursor dan OOT kepada konsumen/pasien, tetapi pelaporan ke dinas kesehatan masih secara manual bahkan masih banyak yang tidak melaporkan penggunaannya ke dinas kesehatan. Penelitian ini bertujuan melakukan pengembangan dan evaluasi aplikasi pelaporan prekursor dan OOT untuk memfasilitasi apotek dalam pembuatan pelaporan secara tepat waktu. Diharapkan pengawasan dan pengendalian dapat dilakukan dengan mudah. Metode yang digunakan dengan menggunakan prinsip penelitian partisipatif berbasis komunitas, kami membagi 3 tahapan metodologi. Salah satu tahapan yang dilaksanakan yaitu pemaparan alur pelaporan prekursor dan OOT. Hasil penelitian ini yaitu memulai pengembangan aplikasi dengan menggunakan pendekatan Rappid Application Development (RAD). Tahapan pada analisis alur pelaporan prekursor dan OOT yaitu admin, user terdaftar, user belum terdaftar, fungsi registrasi, fungsi pelaporan dan fungsi berita dan diskusi. Serangkaian pemodelan diatas digunakan sebagai acuan untuk memasuki tahapan selanjutnya seperti desain antarmuka, desain arsitektur sampai dengan pengkodean.
\end{abstract}

Kata kunci : Aplikasi, Pelaporan, Prekursor, OOT. 


\begin{abstract}
Precursor materials basic ingredients used in manufacture of psychotropics and narcotics. Precursors misused by criminals in the manufacture of psychotropics and narcotics. Precursor abuse usually used as sedative. The abuse narcotics, psychotropic and others drugs containing precursors has decreased along with increasing scrutiny, but recent years abuse has occurred in several other drugs that similar effects to narcotics and psychotropics, drugs with active substance composition of Dextromethorphan and Karisoprodol. After the POM followed up on the abuse by withdrawing single dosage of NIE Dextromethorphan and Karisoprodol, abuse turned to Tramadol, Haloperidol, Trihexyphenidyl, Amytriptyline, Chlorpromazine, hereinafter referred certain drugs (OOT). Pharmacies place that distributes many precursors and OOT to consumers/ patients, but reporting the health office still manual and even many do not report their use health office. This study to develop and evaluate precursor and OOT reporting applications facilitate pharmacies making reports. It is hoped that supervision and control can be carried out easily. The method used by using the principle of community-based participatory research, we divide the 3 stages of the methodology. One of the stages carried out the presentation of the precursor and OOT reporting flow. The result this research to start application development using Rapid Application Development (RAD) approach. The stages in the analysis of the precursor and OOT reporting flow are admin, registered users, unregistered users, registration functions, reporting functions and news and discussion functions. Series of modeling above used as reference to enter the next stage such as interface design, architectural design to coding.
\end{abstract}

Keywords: Applications, Reporting, Precursor, OOT.

\section{PENDAHULUAN}

Prekursor adalah zat atau bahan pemula atau bahan kimia yang digunakan sebagai bahan baku untuk keperluan proses produksi industri farmasi atau produk antara lain sebagai produk ruahan, dan produk jadi yang mengandung ephedrine, pseudoephedrine,norephedrine/phenylprop anolamine, ergotamin, ergometrine, atau Potasium Permanganat (BPOM RI, 2013). Bahan obat prekursor ini banyak digunakan dalam pembuatan obat psikotropika dan narkotika. Prekursor dapat disalahgunakan oleh pelaku kejahatan dalam pembuatan psikotropika dan narkotika. Obat prekursor dapat merugikan dalam penggunaannya apabila terjadi penyalahgunaan atau tidak ada pengawasan yang ketat, salah satu efek merugikan dari penggunaan obat prekursor menyebabkan ketergantungan atau kecanduan. Oleh karenanya, pengawasan precursor farmasi ini harus lebih ditingkatkan (Firdaus, 2020). Apotek adalah sarana pelayanan kefarmasian tempat dilakukan praktik kefarmasian oleh Apoteker. Pelayanan kefarmasian dalah satunya pelayanan kesehatan terkait dengan pengobatan. Standar Pelayanan Kefarmasian merupakan tolak ukur sebagai pedoman bagi tenaga kefarmasian dalam menyelenggarakan pelayanan kefarmasian. 
Apotek memiliki dua fungsi, antara lain memberikan pelayanan kesehatan kepada masyarakat, dan sebagai tempat usaha yang menerapkan prinsip laba. Dengan kata lain, apotek merupakan perwujudan dari praktik kefarmasian dengan fungsi melayani kesehatan masyarakat dengan mengambil keuntungan secara finansial dari transaksi pelayanan kesehatan tersebut. Kedua fungsi apotek tersebut dapat dijalankan secara beriringan tanpa meninggalkan satu sama lain. Pengawasan peredaran bahan baku prekursor farmasi memiliki permasalahan yang kompleks, karena pada satu sisi jika pengawasan yang dilakukan terlalu ketat akan berdampak buruk dalam perkembangan industri sedangkan pada sisi lain pengawasan yang longgar akan mendorong terjadinya penyimpangan (diversi) obat dengan kandungan prekursor oleh sindikat narkoba dalam memproduksi narkotika secara ilegal. Hal yang perlu diwaspadai dalam peredaran obat mengandung prekursor yaitu pembelian dalam jumlah besar dan pembelian secara berulang-ulang dengan frekuensi yang tidak wajar (Aisyah,2019). Kecenderungan ini dilihat dari meningkatnya temuan prekursor farmasi baik dalam bentuk bahan obat maupun obat yang mengandung prekursor pada beberapa tahun terakhir ini.
Hasil survey yang dilakukan terhadap 80 apotek serta Dinas Kesehatan di Kabupaten Banyumas, Purbalingga, Banjarnegara, Cilacap menyatakan untuk pelaporan prekursor dan OOT masih dilakukan secara manual dan tidak rutin setiap bulan bahkan tidak terlapor. Apotek berperan sebagai tempat yang banyak menyalurkan obat prekursor dan OOT dan pelaporan prekursor dan OOT ke Dinas kesehatan yang terjadwal setiap bulan masih dilakukan secara manual, bahkan masih banyak apotek yang tidak melaporkan sehingga mengakibatkan penggunaan prekursor dan OOT tidak bisa dilakukan pengawasan dengan tepat. Hal inilah yang menjadi latar belakang penelitian kami. Oleh karena itu, Penelitian ini bertujuan melakukan pengembangan dan evaluasi aplikasi pelaporan prekursor dan obat-obat tertentu (OOT), untuk memfasilitasi apotek dalam pembuatan pelaporan secara tepat waktu. Sehingga mempermudah dinas kesehatan dalam melakukan pengawasan dan pengendalian penggunaan prekursor dan OOT. Dalam suatu aplikasi terdapat alur pelaporan yang telah ditentukan. Hal ini perlu dilakukan analisis mendalam mengenai alur pelaporan prekursor dan obat-obat tertentu (OOT). 


\section{METODE PENELITIAN}

Metode yang digunakan dengan menggunakan prinsip penelitian partisipatif berbasis komunitas, kami membagi 3 tahapan metodologi dalam membangun aplikasi pelaporan prekursor dan obat-obat tertentu (OOT) yaitu menentukan fungsi utama aplikasi, pengembangan aplikasi dan evaluasi penerima pengguna. Pembuatan aplikasi pelaporan prekursor dan OOT akan menghasilkan luaran berupa Prototype Aplikasi Online pelaporan prekursor dan OOT yang dapat mempermudah dalam pelaporan secara rutin dan tepat waktu.

\section{HASIL DAN PEMBAHASAN}

Tahapan pengumpulan data yang dilakukan terhadap 80 Apotek di 4 Kabupaten yaitu Banjarnegara, Purbalingga, Banyumas dan Cilacap telah dilaksanakan. Masing-masing kabupaten kami lakukan survei sebanyak 20 Apotek. Sebaran apotek di wilayah Karisidenan Banyumas diantaranya (Gambar1), Kabupaten Banjarnegara memiliki 63 Apotek, Purbalingga 82 Apotek, Banyumas 265 Apotek dan Cilacap 165 Apotek. Survei terhadap ketua/sekretaris IAI di setiap kabupaten juga telah kami lakukan termasuk survei terhadap Kepala Bagian Farmasi Dinas Kesehatan Kabupaten.
Tanggapan mereka sangat setuju akan penelitian yang kami buat mengenai pembuatan aplikasi pelaporan prekursor dan OOT. Terutama dinas kesehatan yang sangat senang dengan adanya aplikasi ini nantinya dapat membantu pengecekan penggunaan Prekursor dan OOT di setiap apotek. Dari apotek di 4 kabupaten hanya apotek di kabupaten banyumas yang telah melakukan pelaporan prekursor dan OOT melalui link bit.ly yang dibagikan oleh Dinas Kesehatan Banyumas. Untuk apotek di 3 kabupaten lainnya belum pernah melakukan pelaporan tersebut.

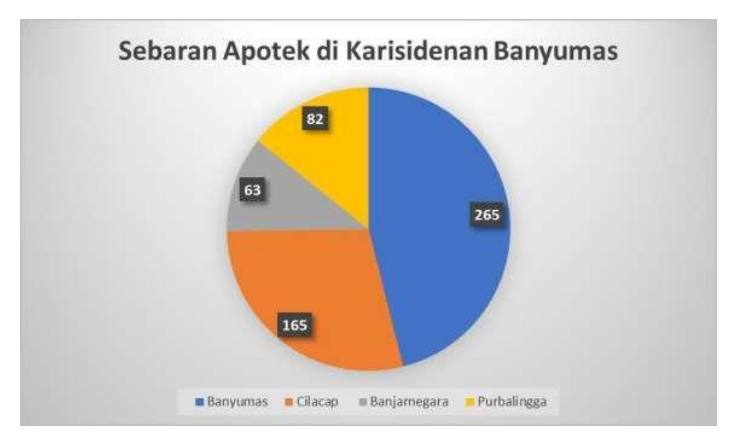

Gambar 1. Sebaran Apotek di Karisidenan Banyumas

Penelitian ini sudah melewati tahapan penentuan fungsi utama aplikasi melalui kesepakatan dengan panel ahli yang terdiri dari beberapa stakeholder, tentang fitur utama aplikasi yang akan dikembangkan. Hasil yang diharapkan adalah panel ahli sepakat dengan tujuan utama pengembangan aplikasi yaitu sebagai media pelaporan obat prekursor dan obat-obatan tertentu yang selama ini belum 
berjalan optimal.

Setelah kesepakatan di tahap sebelumnya tercapai, penelitian ini memulai pengembangan aplikasi dengan menggunakan pendekatan Rappid Application Development (RAD). Metode RAD merupakan pengembangan suatu sistem informasi dengan waktu yang relatif singkat (Aswati,2017). Pendekatan Rapid Application Development digunakan untuk mengantisipasi sifat kolaborasi yang memungkinkan munculnya perubahan pada setiap tahapan pengembangan aplikasi.

Model RAD membutuhkan pendekatan sistematis dalam pengembangan perangkat lunak dari tingkat sistem hingga pemeliharaan (Alexis,2006). Tujuan utama RAD yaitu sistem berkualitas tinggi, pengembangan dan pengiriman cepat, serta biaya rendah. RAD mendistribusikan siklus pengembangan kedalam tahapan analisis, pemodelan, pengembangan, dan pengujian.

1. Pemodelan

\subsection{Diagram Use case}

Diagram use case diperlukan untuk mengetahui fungsionalitas yang telah disediakan oleh sistem. Proses pengidentifikasian pelaku bisnis wajib dilakukan untuk mengetahui siapa saja pengguna sistem. Adapun pelaku bisnis pada sistem ini adalah:
A. Admin

Admin adalah pengguna sistem yang mempunyai otoritas tertinggi di dalam sistem. Admin dapat mengelola konten yang terdapat di sistem sesuai dengan kebutuhan. Mengelola dan menjaga agar sistem tersebut terus berjalan adalah tugas seorang admin.

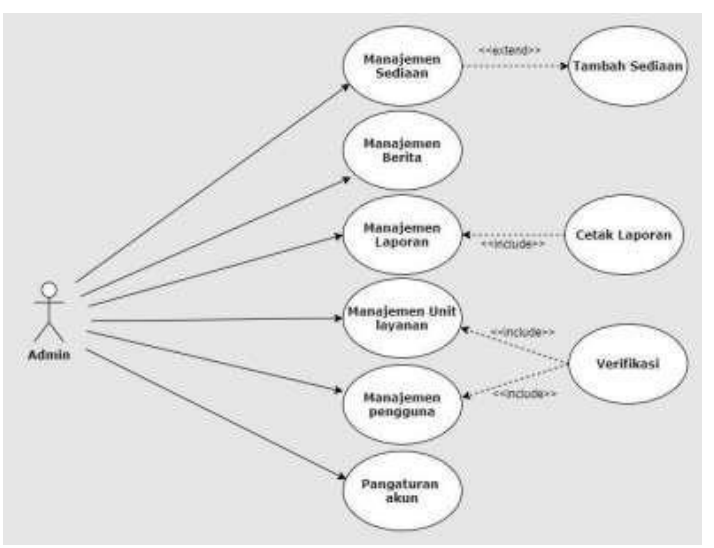

Gambar 2. Use case Admin

B. User Terdaftar

User Terdaftar adalah pengguna yang telah terdaftar di dalam sistem, user terdaftar memiliki otoritas lebih selain $u s e r$ biasa di dalam sistem, adanya kelebihan user terdaftar terdapat hak untuk adalah sebagai berikut:

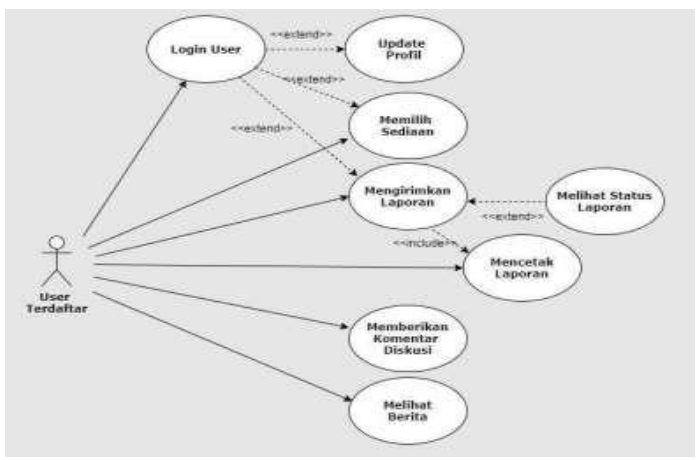

Gambar 3. Use case User Terdaftar 


\section{User Belum Terdaftar}

User belum terdaftar adalah tingkatan pengguna yang paling rendah, pengguna pada tingkat ini hanya melihat sistem secara global, user ini dapat melakukan otorisasi lebih di dalam sistem setelah mendaftar melalui menu yang telah disediakan. Adapun Use case user belum terdaftar adalah sebagai berikut:

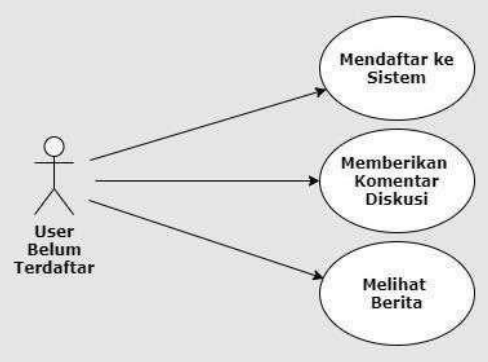

Gambar 4. Use case User Belum Terdaftar

Dari ketiga peran tersebut, terdapat beberapa proses yang menggambarkan use case khusus dari setiap interaksi pelaku bisnis pada sistem tersebut. Tiap pelaku bisnis berinteraksi sesuai dengan proses dimana mereka mengakses sistem. Prosesproses tersebut terbagi menjadi beberapa fungsi, yaitu:

\section{a) Fungsi Registrasi}

Pada use case ini menjelaskan apa saja sebelum proses registrasi, sewaktu proses registrasi, dan sesudah proses registrasi yang di lakukan oleh pelaku bisnis dalam sistem.

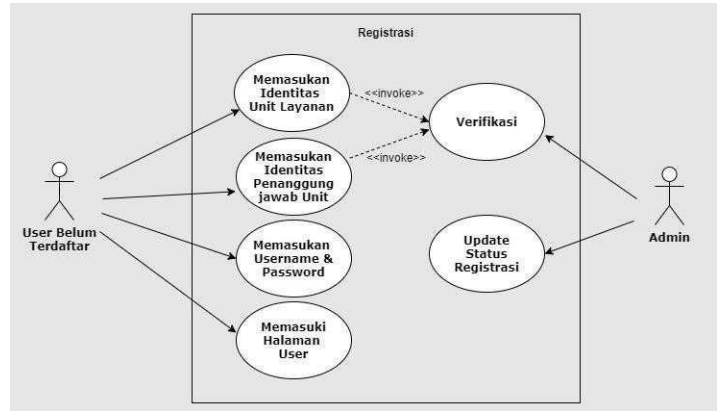

Gambar 5. Use case Fungsi Registrasi

b) Fungsi Pelaporan

Pada Use case ini, fungsi dan proses tentang pelaporan dipaparkan dalam diagram. User terdaftar memilih jenis laporan, kemudian mengirimkan laporan yang berisi sediaan yang dipilih. Dari laporan yang dikirimkan oleh user terdaftar akan ditinjau oleh Admin.

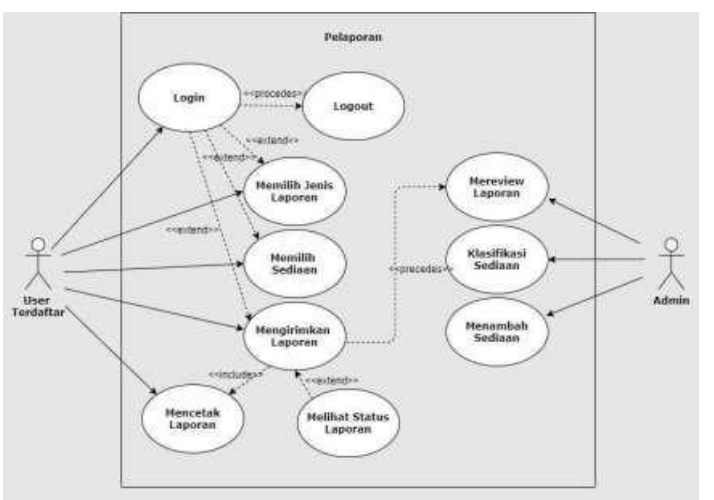

Gambar 6. Use case Fungsi Pelaporan

c) Fungsi Berita dan Diskusi

Pada use case ini menerangkan berita dan diskusi. Berita yang telah diinputkan oleh admin dapat dilihat oleh user, begitu juga diskusi yang telah di postingkan oleh user ataupun admin. 


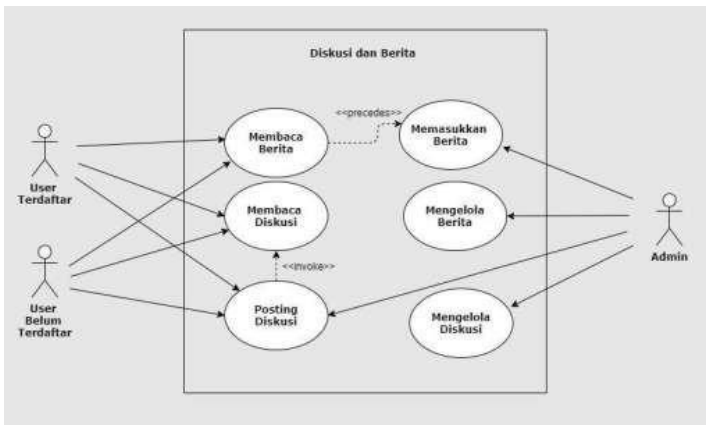

Gambar 7. Use case Berita dan Diskusi

1.2. Representasi grafis alur kerja sistem Pada proses alur kerja sistem yang direpresentasikan dengan bentuk diagram aktivitas atau sering disebut dengan activity diagram. Pada activity diagram, proses alur kerja sistem terbagi menjadi beberapa subproses alur kerja sistem. Adapun beberapa subproses tersebut, yaitu:

\section{A. Alur kerja registrasi}

Pada proses ini direpresentasikan proses mendaftar untuk memperoleh hak akses ke dalam sistem. User melengkapi data registrasi kemudian dilanjutkan proses validasi oleh sistem.

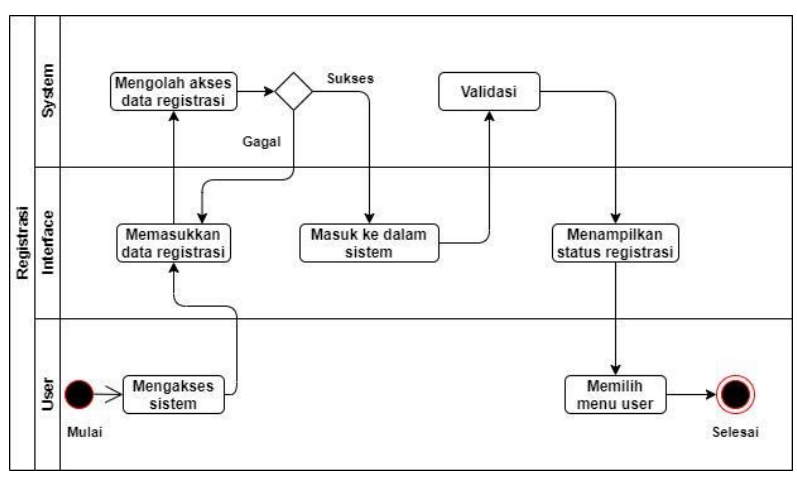

Gambar 8. Activity Diagram Registrasi

B. Alur kerja menambah sediaan

Pada proses ini direpresentasikan proses menambah data sediaan tambahan menjadi master data. Master data sediaan akan menjadi dasar dalam pembuatan laporan.

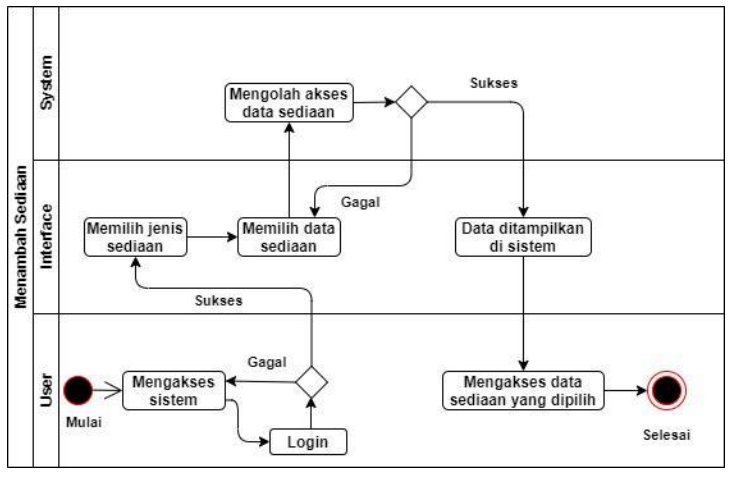

Gambar 9. Activity Diagram Menambah Sediaan

C. Alur kerja pelaporan

Pada proses ini merepresentasikan proses membuat dan mengirimkan laporan. User terlebih dahulu memilih jenis pelaporan kemudian melengkapi, melakukan pemeriksaan kembali dan mengirimkan data laporan.

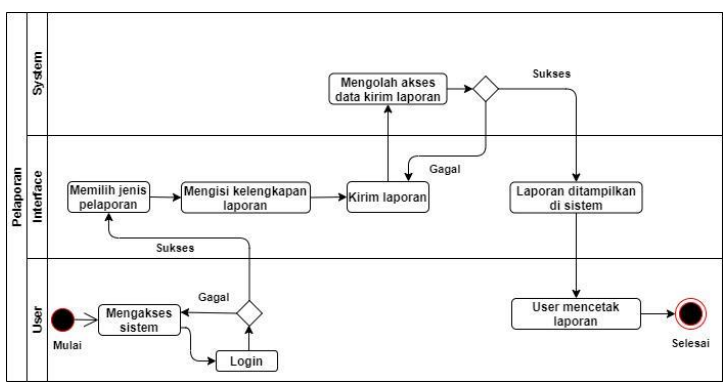

Gambar 10. Activity Diagram Pelaporan

2. Pengembangan

2.1. Rancangan Desain Antarmuka Sistem Setelah melakukan perancangan fungsional maupun non fungsional, perlu dilakukan perancangan desain antarmuka 
sistem. Perancangan antarmuka sistem didasarkan pada bentuk interaksi manusia dan komputer. Proses desain antarmuka sistem di bagi menjadi 2 bagian, yaitu:

A. Perancangan Backend Sistem

Pada perancangan backend sistem ini terbagi menjadi beberapa sub bagian menurut fungsi dan proses dari backend sistem tersebut. Adapun desain dari antar muka backend tersebut meliputi:

a) Menu Dashboard Admin

\section{Menu Dashboard Admin} merupakan tampilan ketika user admin pertama kali melihat sisi backend. Tampilan ini berupa pesan selamat datang dan detail tentang keseluruhan sistem.

b) Menu Sediaan

Menu ini menampilkan manajemen data master sediaan yang nantinya akan menjadi rujukan pengguna dalam proses pembuatan laporan. Pada proses ini terdapat beberapa menu administrator seperti create, read, update, dan delete.

c) Menu User

Menu user menampilkan manajemen data pengguna. Admin bisa melakukan proses administrator seperti create, read, update, dan delete.

d) Menu Unit Layanan

Menu unit layanan menampilkan manajemen unit layanan. Admin bisa melakukan proses administrator seperti melihat dan melakukan verifikasi unit layanan.

e) Menu Laporan

Menu laporan menampilkan manajemen data laporan unit layanan. Dalam proses ini admin bisa melakukan proses administrator seperti melihat, menyetujui, dan mencetak laporan yang dikirim oleh pengguna.

f) Menu Berita

Menu berita menampilkan manajemen data berita dan pengumunan. Admin bisa melakukan proses administrator seperti create, read, update, dan delete.

B. Perancangan Frontend Sistem

Pada perancanan frontend sistem, di desain interface sistem yang berhubungan dengan tampilan langsung kepada user. Segala bentuk informasi yang berguna bagi user ditampilkan dalam tampilan frontend ini.

Tampilan ini terdiri dari beberapa bagian, diantaranya:
a) Tampilan Home
b) Tampilan Menu Profil Penanggung Jawab Unit
c) Tampilan Menu Unit Layanan
d) Tampilan Menu Akun
e) Tampilan Menu Pilih Sediaan 
f) Tampilan Menu Buat Laporan

g) Tampilan Menu Kirim Laporan

\subsection{Implementasi Sistem}

Pada proses implementasi sistem, perancangan yang telah dilakukan percobaan kemudian diimplementasikan dan ditampilkan. Hasil implementasi tersebut berupa user interface, sourcecode, screenshot sistem, dan implementasi database.

Sistem pada aplikasi pelaporan prekursor dan OOT ini menggunakan pemrograman berbasis web, dengan menggunakan HTML, CSS, Javascript, dan Framework YII PHP. Hasil implementasi sistem ini dapat dilihat dari dua sisi, yaitu sisi backend dan sisi frontend. Pada tampilan sisi backend adanya tampilan halaman administrator sebagai media untuk menangani arus data pada sistem. Sedangkan sisi frontend menampilkan data yang bersinggungan langsung dengan pengguna.

Berikut ini adalah beberapa tampilan desain user interface aplikasi yang telah dikembangkan: a) Tampilan halaman utama

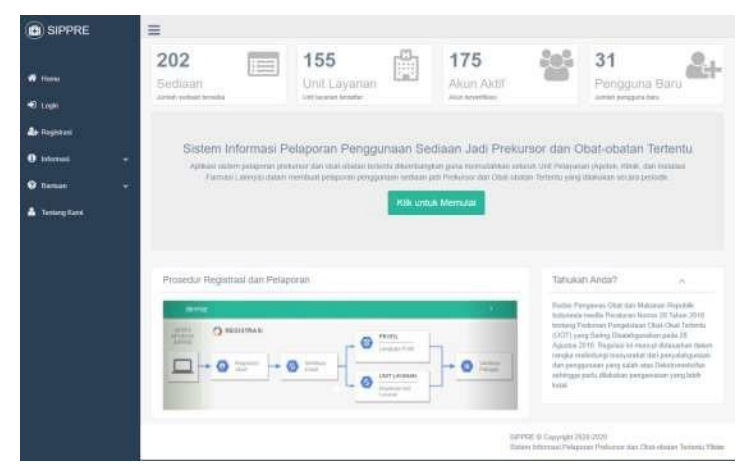

Gambar 11. Halaman utama aplikasi SIPPRE

b) Tampilan halaman login

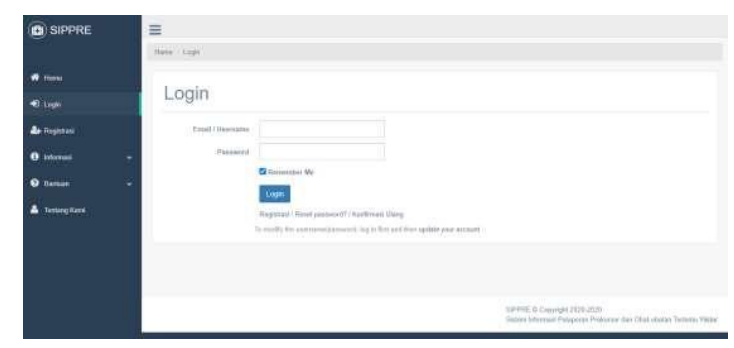

Gambar 12. Halaman login

c) Tampilan halaman beranda user login

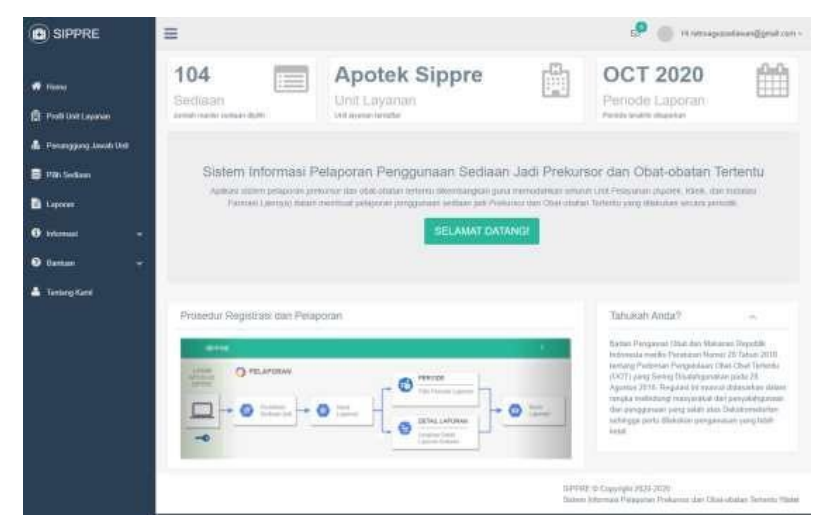

Gambar 13. Halaman beranda user login 
d) Tampilan informasi unit layanan

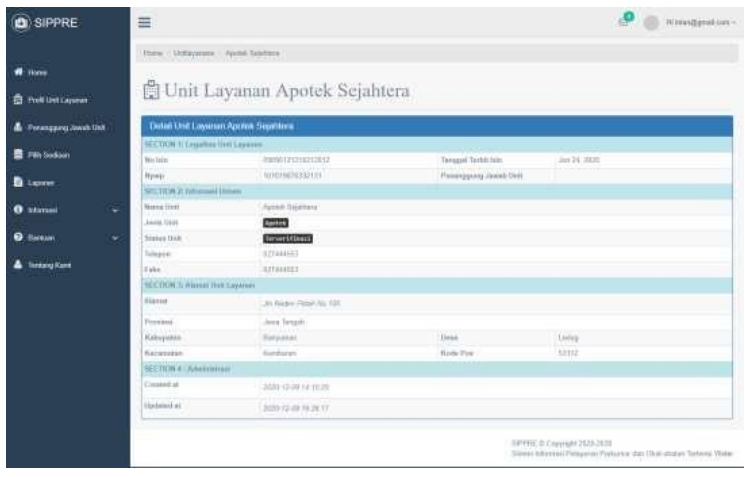

Gambar 14. Halaman informasi unit layanan

e) Tampilan data master sediaan unit layanan

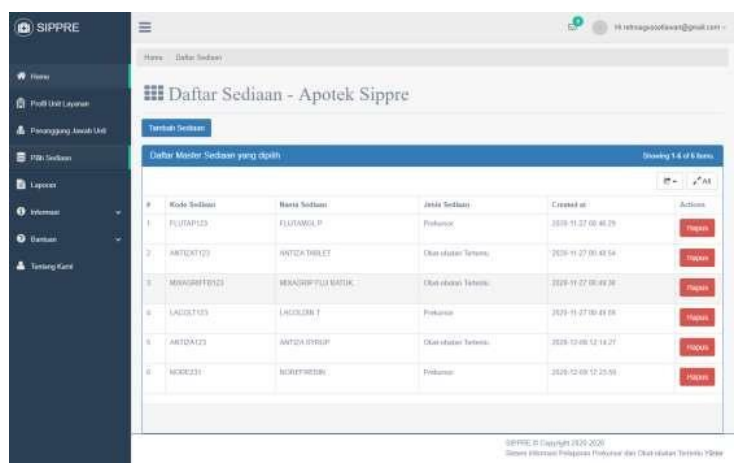

Gambar 15. Halaman daftar sediaan unit layanan

f) Tampilan data laporan unit layanan

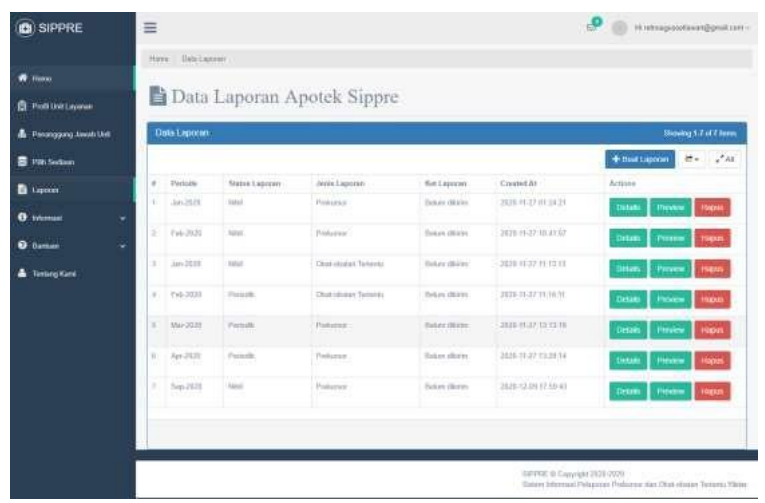

Gambar 16. Halaman data laporan unit layanan g) Tampilan preview laporan unit layanan

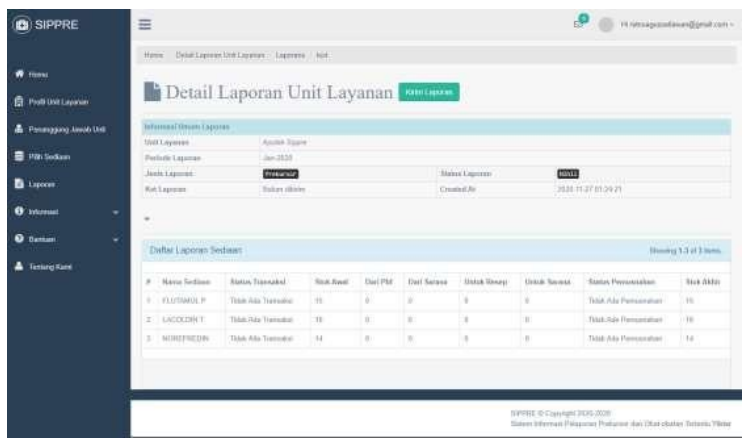

Gambar 17. Halaman preview laporan unit layanan

3. Pengujian

Pengujian pada sistem menggunakan pengujian black box, yaitu pengujian dengan melihat input dan output yang akan dihasilkan dan pengujian white box yaitu pengujian dengan melihat alur test-case untuk melihat kompleksitas logis dari desain prosedural yang terdapat pada sistem tersebut.

A. Pengujian Black Box

Pengujian black box pada sistem aplikasi ini dilakukan dengan menguji tampilan sistem dan juga beberapa testcase yang akan diujikan. Adapun test-case yang akan diujikan tersebut adalah sebagai berikut:

a) Pengujian Fungsi Registrasi

Pengujian fungsi registrasi dilakukan oleh calon pengguna dengan memasukkan data yang dibutuhkan seperti alamat email dan password.

b) Pengujian Memilih Master Sediaan 
Pengujian memilih sediaan dilakukan oleh user yang telah melakukan registrasi akun pada aplikasi yang dikembangkan. Untuk memilih sediaan pengguna login terlebih dahulu ke dalam aplikasi.

c) Pengujian Membuat Laporan

Pengujian ini dilakukan oleh pengguna yang telah melakukan registrasi. Pembuatan laporan pengguna melakukan registrasi unit layanan terlebih dahulu.

d) Pengujian Melengkapi Detail Laporan

Pengujian ini dilakukan oleh pengguna yang sudah melakukan registrasi. Untuk bisa melengkapi detail laporan, pengguna harus membuat laporan terlebih dahulu. Selanjutnya kirim pelaporan dilakukan setelah detail laporan dirasa sudah lengkap.

Berikut adalah beberapa contoh pengujian test-case yang dilakukan:

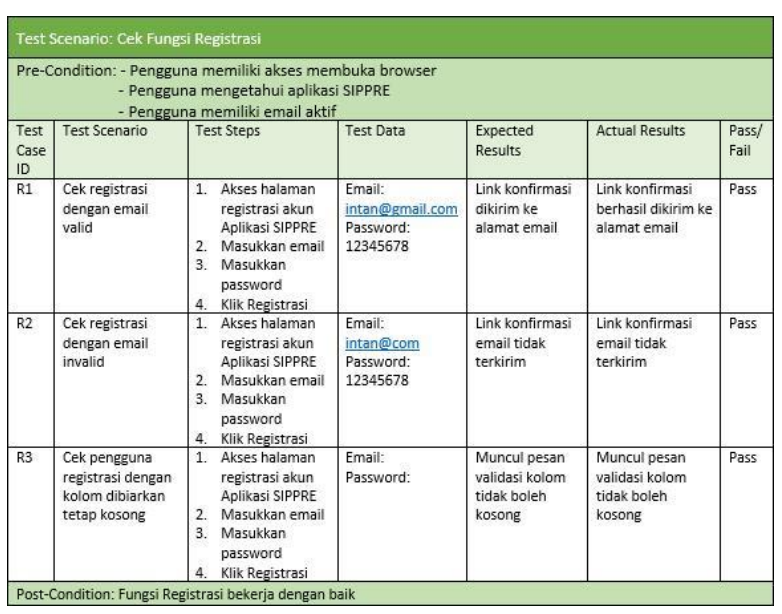

Gambar 18. Pengujian fungsi registrasi

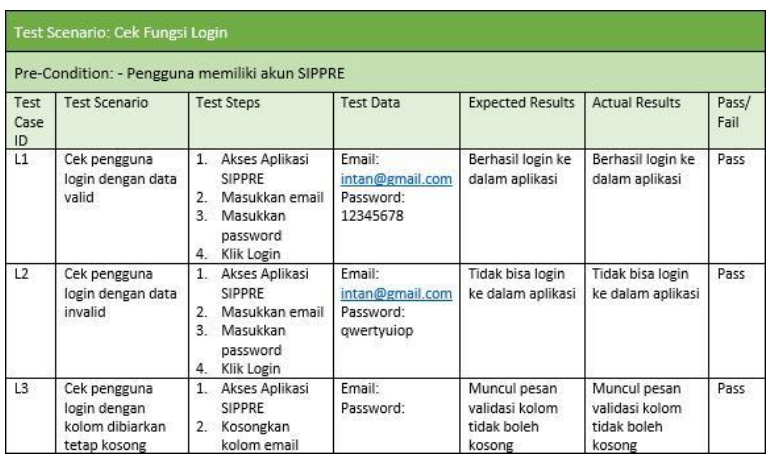

Gambar 19. Pengujian fungsi login

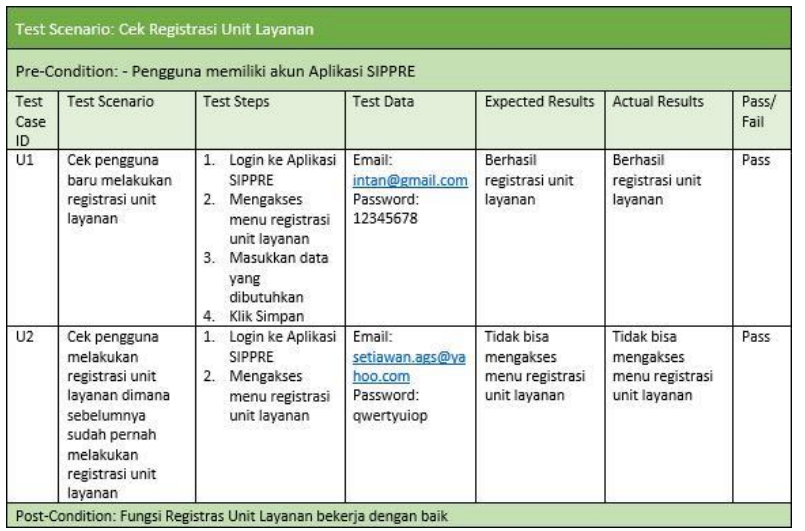

Gambar 20. Pengujian fungsi registrasi unit layanan

\section{B. Pengujian White Box}

Pengujian white box dilakukan dengan menguji proses fungsi tambah sediaan dan kirim pelaporan yang terdapat pada sistem ini.

\section{KESIMPULAN}

Bahan baku prekursor merupakan bahan dasar yang digunakan dalam pembuatan psikotropika dan narkotika. Penyalahgunaan obat dengan kandungan bahan baku prekursor sering terjadi. Apotek sebagai tempat yang banyak menyalurkan obat prekursor dan OOT, memiliki 
tanggung jawab untuk menjaga peredaran obat tersebut yaitu dengan melakukan pelaporan. Pelaporan prekursor dan OOT ke Dinas Kesehatan yang terjadwal setiap bulan masih dilakukan secara manual, bahkan banyak apotek yang tidak melaporkan sehingga mengakibatkan penggunaan prekursor dan OOT tidak bisa dilakukan pengawasan dengan tepat. Dengan menggunakan prinsip penelitian partisipatif berbasis komunitas. Serangkaian tahapan pengembangan dan pemanfaatan aplikasi dapat dilakukan sehingga menjadi aplikasi pelaporan prekursor dan OOT. Penelitian akan menghasilkan luaran berupa Prototype Aplikasi Online pelaporan prekursor dan OOT yang dapat mempermudah dalam pelaporan secara rutin dan tepat waktu.

\section{DAFTAR PUSTAKA}

Aisyah, N., Rahmida, D., Saputera, M. M.

A., \& Dina, S. P. (2019).

KOMPARASI PENJUALAN OBAT

PREKURSOR SEBELUM DAN

SESUDAH INSPEKSI BPOM DI

APOTEK KIMIA FARMA 61

VETERAN BANJARMASIN

TAHUN 2017. Jurnal Insan Farmasi

Indonesia, 2(1), 89-97.

Alexis Leon., (2006). Database

development life cycle.
Aswati, S., Ramadhan, M. S., Firmansyah, A. U., \& Anwar, K. (2017). Studi Analisis Model Rapid Application Development Dalam Pengembangan Sistem Informasi. MATRIK: Jurnal Manajemen, Teknik Informatika dan Rekayasa Komputer, 20-27.

Bogadenta, (2012). Manajemen Pengelolaan Apotek. Yogyakarta: DMedika.

Firdaus, B. Y., Saputri, R. K., \& Zuhriyah, A. (2020). PENGELOLAAN PENYIMPANAN DAN PENYERAHAN OBAT PREKURSOR DI APOTEK AISYA FARMA BOJONEGORO. JAPRI: Jurnal Penjas dan Farmasi, 3(1), 2132.

M. Chaudhry, L. Faust, and N. V. Chawla, "Development and Evaluation of a Web Application for Prenatal Care Coordinators in the United States," in 14th International Conference on Design Science Research in Information Systems and Technology, DESRIST (2019) Worcester, MA, USA, June 4-6, 2019, Proceedings, vol. 11491, Springer International Publishing, 2019, pp. 140-156.

BPOM RI, (2013). "Peraturan Kepala Badan Pengawas Obat dan Makanan 
Republik Indonesia Nomor 40 Tahun 2013 tentang Pedoman Pengelolaan Prekursor Farmasi dan Obat Mengandung Prekursor Farmasi," Jakarta.

BPOM RI, (2016). "Peraturan Kepala Badan Pengawas Obat dan Makanan Republik Indonesia Nomor 7 Tahun 2016 tentang Pedoman Pengelolaan Obat-Obat Tertentu yang Sering Disalahgunakan,” Jakarta.

BPOM RI, (2012). "Peraturan Kepala Badan Pengawas Obat dan Makanan Republik Indonesia Nomor HK.03.1.34.11.12.7542 Tahun 2012 tentang Pedoman Teknis Cara Distribusi Obat Yang Baik,".

Menkes RI, (2016). "Peraturan Menteri Kesehatan Republik Indonesia Nomor 73 Tahun 2016 Tentang Standar Pelayanan Kefarmasian di Apotek," Jakarta.

Menkes RI, (2017). "Peraturan Menteri Kesehatan Republik Indonesia Nomor 9Tahun 2017 Tentang Apotek," Jakarta.

Menkes RI, (2015). "Peraturan Menteri Kesehatan RI Nomor 3 Tahun 2015 tentang Peredaran, Penyimpanan, Pemusnahan dan Pelaporan Narkotika, Psikotropika dan Prekursor Farmasi,” Jakarta. 